\title{
PEMBERDAYAAN YATIM DAN DHUAFA MELALUI PROGRAM “SHORT COURSE” (KURSUS SINGKAT) RUMAH GEMILANG INDONESIA SAWANGAN DEPOK
}

\section{DOI: https://doi.org/10.38214/jurnalbinaummatstidnatsir.v4i1.100}

\author{
SALMAN ALFARISI \\ salman@stidnatsir.ac.id \\ STID Mohammad Natsir, \\ Indonesia
}

\author{
ZULIA FAJARWATI \\ Zulia.fajarwati@gmail.com \\ STID Mohammad Natsir, \\ Indonesia
}

\begin{abstract}
ABSTRAK
Tujuan penelitian: Tujuan dilakukannya penelitian ini adalah untuk mengetahui Pemberdayaan yatim dan Dhuafa melalui program short course (kursus singkat) Rumah Gemilang Indonesia Sawangan Depok. Metode penelitian, jenis penelitian ini adalah penelitian lapangan (field research), yaitu penelitian dan pengambilan datanya dilakukan di lapangan, dengan menggunakan pendekatan kualitatif dengan metode deskriptif kualitatif. Hasil penelitian, Berdasarkan hasil penelitian yang peneliti lakukan bahwa Rumah Gemilang Indonesia Sawangan Depok telah banyak melakukan aktifitasnya dalam hal pemberdayaan terhadap Yatim dan Dhuafa melalui program short course dan telah mendapatlkan dampak yang sangat positif bagi para peserta didikinya. Uapaya-upaya pemberdayaan yang dilakukan oleh Rumah Gemilang Indonesia Sawangan Depok antara lain pertama, Menyadarkan akan potensi yang dimiliki oleh para peserta, Kedua, Menfasilitasi untuk pengembangan potensi yang dimiliki oleh para peserta. Ketiga, Penanaman nilai-nilai kepada para peserta. Keempat, menumbuhkan sifat semangat Partisipasi kepada peserta, Kelima, Mengarahkan pada tempat yang tepat.
\end{abstract}

Kata Kunci: pemberdayaan, yatim dan dhuafa, short course, rumah gemilang indonesia

\section{PENDAHULUAN}

Pemberdayaan merupakan upaya memenuhi kebutuhan yang diinginkan oleh individu, kelompok dan masyarakat luas agar mereka 
memiliki kemampuan untuk melakukan pilihan dan mengontrol lingkungannya agar dapat memenuhi keinginan-keinginannya, termasuk aksebilitas terhadap sumber daya yang terkait dengan pekerjaannya, aktivitas sosialnya, dll. ${ }^{1}$

Namun pada kenyataannya pemberdayaan untuk menanggulangi pengangguran sangatlah minim. Saat ini tercatat 7,4 juta pengangguran dari total penduduk 250 juta jiwa di Indonesia, tetapi hal ini juga tidak boleh dibiarkan sebab pengangguran yang berkepanjangan dapat menimbulkan efek psikologis yang buruk terhadap pengangguran dan keluarganya. Hal itu menyebabkan kekacauan politik, keamanan sosial, serta mengganggu pertumbuhan dan pembangunan ekonomi suatu negara. ${ }^{2}$

Kurangnya pemberdayaan anak yatim dan dhuafa menyebabkan hilangnya harapan mereka untuk menjalani hidupnya, terutama bagi anak yang kurang mampu. Solusinya adalah dengan menampung dan melayani anak yatim yang berasal dari keluarga tidak mampu, tujuannya untuk membantu mereka agar dapat menyelesaikan pendidikannya baik formal atau non formal, karena mereka harus mendapatkan perhatian yang serius, agar mereka tidak terlantar karena keterbatasan ekonomi keluarganya. Mereka harus dibantu agar bangkit dari keterpurukan dengan cara merangkul dan mengenalkan mereka dengan pendidikan, sehingga kita memiliki calon-calon pemimpin yang memadai di masa mendatang. ${ }^{3}$

Jika kaum Yatim dan Dhuafa mengalami ketidak mampuan dalam menempuh jenjang pendidikan menyebabkan mereka tidak mengenal dunia pendidikan, baik pendidikan formal ataupun non formal, maka akibatnya pengetahuan mereka pun tertinggal, bakat dan kekreatifan mereka tidak dapat berkembang dengan luas, tanpa adanya pembinaan karakter yang baik. Sedangkan pendidikan merupakan salah satu tolak ukur kemajuan suatu bangsa karena pendidikan menjadi kualitas sumber daya manusia.

1 Aprillia Theresia, Krisnha, Dkk. Pembangunan Berbasis Masyarakat, (Bandung: Alfabeta, 2015) cet.2, hal.117

2 Dwi Kartina Ningsih, Satu Langkah Untuk Indonesia Gemilang, diakses dari http://Rumahgemilang.com/satu-langkah-untuk-Indonesia-gemilang/ pada tanggal.5 Juli 2019 pukul.23.00

3 Nahdiyah, Bab I pendabuluan A.Latar Belakang Penelitian, diakses dari https://www.google.com/url?sa=t\&source=web\&rct=i\&url=http://digilib.uinsgd.ac.id/1 1570/4/4 bab1.pdf\&ved=2ahUKEwil7I juebrAhXkILcAHVuNBJwQFjAAegQIAhAB\& usg=AOvVaw0VEj4mrN0eNkMy08CRxqQ6 pada tanggal 5 juli 2019, pukul 02.00 
Pendidikan merupakan salah satu solusi bagi permasalahan kemiskinan secara jangka menengah atau jangka panjang. Mahalnya biaya pendidikan atau tidak adanya biaya orang miskin untuk menempuh jenjang pendidikan karena lebih mengutamakan biaya untuk makan, menyebabkan orang miskin tidak mampu memperoleh pendidikan yang bermutu. ${ }^{4}$ Kemiskinan dan kurangnya kemauan untuk berusaha terus menuntut ilmu adalah salah satu indikator penyebab dari kebodohan. Pendidikan disini tidak diartikan pendidikan formal saja, akan tetapi dalam arti lebih luas.

Sebagai upaya untuk mengurangi probelematika di atas, hadir sebuah lembaga yang bernama RGI (Rumah Gemilang Indonesia) yang memiliki misi "menjadi pusat pendidikan dan pelatihan keterampilan serta pengembangan masyarakat yang mampu menciptakan generasi kreatif, produktif, mandiri dan berakhlaq mulia", untuk yatim dan dhuafa. RGI berupaya untuk memberikan bekal pelatihan keterampilan bagi anak-anak usia muda yang berpotensi menjadi bibit baru pengangguran diusia muda. Saat ini terdapat empat bidang studi keterampilan yang dibentuk ileh lembaga ini yaitu; kelas desain grafis, menjahit dan tata busana, teknik Komputer dan Jaringan, fotografi dan vidiografi, aplikasi perkantoran, dan Kelas otomotif.

Program tersebut telah menjadi program regular di setiap tahunnya yang telah meluluskan kurang lebih 150 usia produktif siap kerja dan berwirausaha dalam dua priode angkatan. Juli 2013 RGI telah meluluskan kurang lebih 630 anak usia 17-30 tahun yang berbekal keahlian untuk siap melakukan perubahan terhadap masa depannya dan mampu terjun ke masyarakat memberikan perubahan yang positif. ${ }^{5}$

Sejak tahun 2009 RGI melangkah ke depan untuk menjadi trendsetter model solusi pengurangan angka pengangguran, khususnya usia produktif yatim dan dhuafa ${ }^{6}$. Para alumni RGI tersebar hingga ke 89 kota di Indonesia. Mereka tidak hanya bekerja untuk diri mereka sendiri, melainkan berkontribusi secara sosial untuk lingkungan dan masyarakat sekitarnya. Hingga saat ini, lebih dari 30 bisnis baru dikembangkan oleh para alumni

${ }^{4}$ Rabina Yunus dan Mansyur Radjab, Ananlisis Pengentasan Kemiskinan, (Makasar: CV.Sosial Politic Genius, 2018) cetakan pertama, hlm.41

${ }^{5}$ Dwi Kartika Ningsi, Satu Langkah Untuk Indonesia Gemilang, diakses dari http://rumahgemilang.com/satu-langkah-untuk-Indonesia-gemilang/ pada tanggal 3 juli 2019, pukul 11.20

${ }^{6}$ Rumah Gemilang Indonesia, Trendsetter Pemberdayaan Produktif, diakses dari http://rumahgemilang.com/trendsetter/ pada tanggal 5 juli 2019, pukul 03.40

29 | Bina Ummat | Vol 4 | No. 1 | 2021 
untuk meningkatkan kesejahteraan kehidupan mereka. Lebih dari $80 \%$ para alumni telah menghasilkan dan dapat berkontribusi membantu ekonomi keluarga. ${ }^{7}$

Bahkan ada salah satu bukti nyata keberhasilan pemberdayaan yang dilakukan oleh RGI, yaitu kisah mantan OB yang sukses keliling dunia berkat RGI. Yaitu Muhammad Iqbal (24 th) yang hanya mampu mengenyam dunia pendidikan sampai SD, sebelumnya Iqbal bekerja sebagai OB (Office Boy) disebuah bank di kawasan Jakarta. Iqbal adalah peserta RGI ke delapan dengan jurusan fotografi dan videografi yang lulus pada tahun 2013. Setelah lulus, RGI mengantarkannya menjadi seorang editor video dan cameramen di PH (Production House) di Jakarta Selatan, dengan lokasi syuting yang mengambil gambar di luar negeri menjadikan Iqbal bisa berkeliling dunia tanpa mengeluarkan biaya pribadi. ${ }^{8}$

Sama halnya dengan yang dialami oleh Marino Nugroho sebagai bukti keberhasilan RGI dalam pemberdayaannya. Yang mana dulunya Marino hanya sebagai tukang las, namun kini ia sukses menjadi pengusaha Neon Box. Sebelumnya menjadi seorang pebisnis, tidak pernah terbayangkan oleh Marino Nugroho (31 th). Apalagi ia mengaku tidak memilki bakat dan pendidikan untuk menjadi pengusaha, sekolah pun tak tamat SMA, karena saat masih muda ia banyak habiskan waktunya untuk hura-hura di jalanan. Dan pada tahun 2015 Marino masuk ke Rumah Gemilang Indonesia (RGI), program pembinaan generasi produktif binaan LAZ Al Azhar dan mengambil jurusan desain grafis. Dan selama di RGI Marino juga berhasil memperbaiki dirinya. Ia tak hanya belajar cara desain, layout dan lainnya, tapi juga belajar bagaimana untuk memahami agama Islam secara benar. ${ }^{9}$

RGI adalah sebuah tempat pusat pemberdayaan bagi usia produktif yatim dan dhuafa dengan model kelas training. Panduan konsep harmoni antara system pendidikan ala pesantren dan pendidikan vokasi menjadi

${ }^{7}$ Rumah Gemilang Indonesia, Trendsetter Pemberdayaan Produktif, diakses dari http://rumahgemilang.com/trendsetter/ pada tanggal 5 juli 2019, pukul 03.30

8Ridhuan Habibie, "Kisah Mantan OB Yang Sukses Keliling Dunia Berkat RGI", diakses dari https://m.liputan6.com/citizen6/read/2852038/kisah-mantan-ob-yangsukses-keliling-dunia-berkat-rgi pada tanggal 8 Juli 2019, pukul 06.45

${ }^{9}$ Arie Liliyah, "Mrino : Tukang Las ini Sukses Jadi Pengusaha Neon Box", diakses dari https://swa.co.id/kumparan/marino-tukang-las-yang-sukses-jadi-pengusaha-neonbox pada tanggal 14 September 2019, pukul 19.30 
dasar pengembangan pola pendidikan di Rumah Gemilang Indonesia. Pada saat proses diklat, mereka tidak hanya dibekali dengan pengetahuan umum untuk mendorong peningkatan keilmuan dan keterampilan, namun juga bekal pengetahuan agama seperti pemahaman aqidah yang lurus, akhlaqul karimah, kedisiplinan dalam beribadah dan nilai-nilai keagamaan lainnya. Selama kurang lebih 5 hingga 6 bulan para ini dibina untuk bertransformasi menjadi berkeahlian, berwawasan dalam bidang pengetahuan agama, berakhlaq yang baik, punya jiwa sosial yang tinggi serta berkarakter pemimpin masa depan.

Lembaga RGI mendukung pesantren platform, tetapi focus pada penyelenggaraan pendidikan non formal dalam kemasan Short Course (Kursus singkat). Perpaduan ini dimaksudkan agar pada peserta pelatihan RGI tidak hanya menyerap pengetahuan-pengetahuan dan keterampilan yang lebih baik daripada pondasi masa depan mereka, tetapi juga memiliki pengetahuan dan dasar akidah iman yang baik. ${ }^{10}$ Pendidikan dan pelatihan juga merupakan sarana yang dapat dipergunakan oleh individu untuk dapat mengembangkan diri dan memunculkan potensi dirinya yang mungkin masih terpendam untuk dapat dioptimalkan menjadi sebuah kekuatan besar dalam mencapai segala tujuan pribadi. ${ }^{11}$

Berdasarkan uraian di atas, maka saya mencoba untuk melakukan penelitian lebih dalam dengan judul "Pemberdayaan Yatim dan Dhuafa melalui program "Short Course" (Kursus Singkat) Rumah Gemilang Indonesia".

\section{Pemberdayaan}

Menurut definisinya, pemberdayaan diartikan sebagai upaya untuk memberikan daya (empowerment) atau penguatan (strengthening) kepada masyarakat (Mas'oed, 1990). Keberdayaan masyarakat oleh Sumodiningrat (1997) diartikan sebagai kemampuan individu yang bersenyawa dengan

\footnotetext{
${ }^{10}$ Rumah Gemilang, Sejarah Singkat, diakses dari Rumahgemilang.com/profil/sejarah-singkat/, pada tanggal 3 juli 2019, pukul 11.30

${ }^{11}$ Muwafik Saleh, Manajemen Training: Teknik Praktis Pengelolaan Training dan Pelatiban Sumber Daya, (Malang: UB Press, 2016), cet.pertama, hlm.8
} 
masyarakat dalam membangun dalam keberadaan masyarakat yang bersangkutan. ${ }^{12}$

Istilah pemberdayaan, juga dapat diartikan sebagai upaya memenuhi kebutuhan yang diinginkan oleh individu, kelompok dan masyarakat luas agar mereka memiliki kemampuan untuk melakukan pilihan dan mengontrol lingkungannya agar dapat memenuhi keinginan-keinginannya, termasuk aksebilitas terhadap sumber daya yang terkait dengan pekerjaannya, aktivitas sosialnya, dll.

Pemberdayaan adalah suatu cara agar rakyat, komunitas, dan organisasi diarahkan agar mampu menguasai atau berkuasa atas kehidupannya (Rappaport, 1984). Pemberdayaan adalah sebuah proses agar setiap orang menjadi cukup kuat untuk berpartisipasi dalam berbagai pengontrolan dan mempengaruhi kejadian-kejadian serta lembaga-lembaga yang mempengaruhi kehidupannya. Pemberdayaan menekankan bahwa orang memperoleh keterampilan, pengetahuan, dan kekuasaan yang cukup untuk mempengaruhi kehidupannya dan kehidupan orang lain yang menjadi perhatiannya. (parsons, et al, 1994). ${ }^{13}$

Dalam rangka pemberdayaan, upaya yang amat pokok adalah peningkatan taraf pendidikan, dan derajat kesehatan, serta akses ke dala sumber-sumber kemajuan ekonomi seperti modal, teknologi, informasi, lapangan kerja, dan pasar. Masukan berupa pemberdayaan ini menyangkut pembangunan prasarana dan sarana dasar fisik, seperti irigasi, jalan, listrik, maupun sosial seperti sekolah dan fasilitas pelayanan kesehatan, yang dapat dijangkau oleh masyarakat pada lapisan paling bawah, serta ketersediaan lembaga-lembaga pendanaa, pelatihan, dan pemasaran di perdesaan, di mana terkonsentrasi penduduk yang keberdayaannya amat kurang. Untuk itu, perlu ada program khusus bagi masyarakat yang kurang berdaya, karena program-program umum yang berlaku tidak selalu dapat menyentuh lapisan masyarakat. ${ }^{14}$

Dalam bidang pendidikan, pemberdayaan dapat diartikan sebagai upaya keaksaraan atau pemberantasan 3-nuta (huruf, angka, pengetahuandasar) dan pelatihan yang lain, sehingga mereka mampu menggali kearifan

12 Aprillia Theresia, Krisnha, Dkk. Pembangunan Berbasis Masyarakat, (Bandung: Alfabeta, 2015) cet.2, hal.115

${ }^{13}$ Ibid cet.2 hal.117

${ }^{14}$ Aprillia Theresia, Krisnha, Dkk. Pembangunan Berbasis Masyarakat, cet.2, hal.119 
tradisional, dan mudah mengadopsi inovasi yang bermanfaat bagi kehidupan keluarga dan masyarakatnya.

Pemberdayaan dalam bidang pendidikan, merupakan proses "penyadaran" (freire...) baik penyadaran tentang keberadaannya, masalahmasalah yang dihadapi, kebutuhan untuk memecahkan masalah, peluangpeluangyang dapat dimanfaatkan, serta penyadaran tentang pilihan-pilihan yang terbaik untuk diri sendiri dan masyarakatnya. Lebih lanjut, Free (1973) juga mengartikan pemberdayaan dalam bidang pendiidikan merupakan praktik pembebasan diri dari ketidaktahuan, tekanan-tekanan, dan lain-lain hal yang membelenggu seseorang dan atau kelompok masyarakat untuk memperbaiki kehidupannya. Pendidikan sebagai praktik pembebasan, juga termasuk membebaskan diri dari symtem sekolah (Illich, 1976)

Pemberdayaan dalam bidang pendidikan, juga berarti kemampuan dan keberanian untuk melakukan per ubahan sosial, ekonmi, politik, maupun budaya untuk terus menerus memperbaiki kehidupan. ${ }^{15}$

\section{Teori Upaya Pemberdayaan Masyarakat}

Dalam penelitian ini penulis mengunnakan teori pemberdayaan dalam pandangan Kartasasmita (1997:11-12) pemberdayaan adalah upaya untuk meningkatkan harkat dan martabat lapisan masyarakat yang dalam kondisi sekarang tidak mampu melepaskan diri dari perangkap kemiskinan dan keterbelakangan. dengan kata lain pemberdayaan adalah memapukan dan memandirikan masyarakat dalam kerangka pemikiran itu, upaya pemberdayaan masyarakat haruslah dilakukan dengan;

a. Menciptakan suasana atau iklim yang memungkinkan potensi masyarakat berkembang. Di sini titik tolaknya adalah pengenalan bahwa setiap manusia atau setiap masyarakat memiliki potensi yang dapat dikembangkan. Artinya tidak ada masyarakat yang sama sekali tanpa daya. Pemberdayaan adalah upaya untuk membangun daya itu, dengan motivasi dan mengembangkan kesadaran akan potensi yang dimilikinya serta berupaya untuk mengembangkannya.

b. Upaya itu harus diikuti dengan memperkuat potensi atau daya yang dimiliki oleh masyarakat

15 Aprillia Theresia, Krisnha, Dkk. Pembangunan Berbasis Masyarakat, cet.2, hal.121

33 | Bina Ummat | Vol 4 | No. 1 | 2021 
c. Dalam rangka ini diperlukan langkah-langkah lebih positif, selain dari hanya menciptakan iklim atau suasana. Perkataan ini meliputi langkahlangkah nyata, dan menyangkut penyediaan berbagai masukan (input) serta pembukaan akses kepada berbagai peluang yang akan membuat masyarakat makin berdaya

d. Pemberdayaan bukan hanya meliputi penguatan individu anggota masyarakat, tetapi juga pranata-pranatanya. Menanamkan nilai-nilai budaya modern, seperti kerja keras, hemat, keterbukaan, tanggung jawab adalah bagian pokok dari upaya pemberdayaan ini. Demikian pula pembaharuan lembaga-lembaga sosial dan pengintegrasiannya ke dalam kegiatan pembangunan serta peranan masyarakat di dalamnya.

e. Meningkatkan partisipasi masyarakat dalam pengambilan keputusan. Dengan dasar pandangan demikian, maka pemberdayaan masyarakat sangat erat kaitannya dengan pemantapan, pembudayaan, dan pengalaman demokrasi.

f. Pemberdayaan juga mengandung arti melindungi. Dalam proses pemberdayaan, harus dicegah yang lemah menjadi bertambah lemah, oleh karena kekurangberdayaan dalam mengahadapi yang kuat. Oleh karena itu, perlindungan dan pemihakan kepada yang lemah sangat mendasar sifatnya dalam konsep pemberdayaan. Melindungi tidak berarti mengisolasi atau menutupi dari interaksi karena hal itu, justru akan mengerdilkan yang kecil dan melunglaikan yang lemah. melindungi harus dilihat sebagai upaya untuk mencegah terjadinya persaingan yang tidak seimbang, serta eksploitasi yang kuat atas yang lemah. ${ }^{16}$ Dalam artian mengarahkan masyarakat pada tempat yang tepat sesuai dengan potensi yang dimilikinya.

Menurut teori ini pemberdayaan adalah upaya untuk mengentaskan masyarakat dari ketidak berdayaan atau mengeluarkan masyarakat dari kondisi yang tidak mampu melepaskan dirinya dari perangkap kemiskinan dan keterbelakangan.

Asumsi dasar dari teori ini adalah jika ingin melakukan kegiatan pemberdayaan maka dibutuhkannya upaya-upaya pemberdayaan. Yang mana dari upaya-upaya tersebut adalah sebagai bentuk ikhtiar untuk menuju pemberdayaan yang sukses. Dan salah satu tujuan dari upaya-upaya pemberdayaan tersebut adalah memampukan dan memandirikan kaum yang lemah.

${ }^{16}$ Abu Huraerah, Pengorganisasian dan Pengembangan Masyarakat, cet.1 hal.101 


\section{DefinisiYatim}

Kata "Yatim" berasal dari akar kata ya-ta-ma". Menurut arti kata "Yatim" berarti yang perlu dikasihani. Secara sederhana, pengertian yatim adalah anak yang ditinggal mati oleh ayahnya di usia sebelum baligh.

Dalam sebuah hadits dari Anas ra., menyatakan bahwa, Rasulullah bersabda; "Tidak disebut sebagai anak yatim ketika dia telah bermimpi bingga keluar air mani”. (HR.Abu Hanifah) ${ }^{18}$

\section{Definisi Dhuafa}

Makna Dhu'afa dalam kosa kata Al-Qur'an merupakan bentuk jamak dari kata "dha'if". Kata ini berasal dari akar kata "dha'afa atau dha'ufayadh'afu-dhu'fan atau dha'fan" 19 yang secara umum mengandung dua pengertia, lemah dan berlipat ganda. Menurut al-Ashfahani perkataan dhu'fu merupakan lawan dari quwwah yang berarti kuat.

Dari segi kata dha'if mempunyai dua arti, pertama berarti lemah kedua berarti berlipat ganda seperti contoh ayat yang mengandung arti bertambah atau berlipat ganda. Yaitu dalam surat An-Nisa' ayat 28, yaitu:

Artinya: "Allah hendak memberikan keringanan kepadamu, dan manusia dijadikan bersifat lemah.” (Qs.An-Nisa':28) ${ }^{\mathbf{2 0}}$

\section{Definis Short Course}

Short dalam kamus bahasa Inggris adalah Pendek ${ }^{21}$, sedangkan menurut Kamus Besar Bahas Indonesia pendek adalah sebentar, ringkas singkat.

Istilah Course merupakan kata bahasa Inggris yang terjemahannya adalah kursus, yang secara harfiah berarti "mata pelajaran atau rangkaian mata pelajaran". PP N. 73 tahun 1991 tentang peran pendidikan luar

${ }^{17}$ Achmad Sya'bi, Kamus An-Nur, (Surabaya: Halim Jaya, 1997) hal.309

18 Ben Akrom Kasyaf S., Dasyatnya Menyantuni Anak Yatim, (Jakarta Timur: Al Maghfiroh, 2012) cet.1 hal.1

${ }^{19}$ Achmad Sya'bi, Kamus An-Nur, (Surabaya: Halim Jaya, 1997) hal.130

${ }^{20}$ Nurdiana Ratna Sari, Sekripsi Pengembangan Anak Dhu'afa Melalui Pendidikan Non Formal Di Yayasan Mizan Amanah, (Jakarta: Universitas Islam Negeri Jakarta, 2011) hal.23

${ }^{21}$ Desy Anwar, Kamus Lengkap 100 Miliard, (Surabaya: Amelia) hal.276 
sekolah, dijelaskan bahwa kursus adalah, satuan pendidikan nonformal yang terdiri atas sekumpulan warga masyarakat yang memberikan pengetahuan, keterampilan, dan sikap mental tertentu bagi warga belajar. Kartasasmita (1985) mengatakan, kursus sebagai mata kegiatan pendidikan yang berlansungdi dalam masyarakat yang dilakukan secara sengaja, terorganisir, dan sistematisuntuk memberikan materi pelajaran tertentu kepada orang dewasa atau remaja dalam waktu yang relative singkat agar mereka memperoleh pengetahuan, sikap dan keterampilan yang dapat dimanfaatkan untuk mengembangkan dari masyarakat. Contoh, kursus menjahit, computer, bengkel, kecantikan.

Kursus adalah kegiatan yang dilaksanakan dan diseleggarakan oleh masyarakat, di tengah masyarakat, dan berdasarkan kebutuhan yang dirasakan oleh masyarakat itu sendiri. ${ }^{22}$

Beberapa literature menyebutkan bahwa kursus didefinisikan dalam keputusan Direktur Jenderal Pendidikan Luar Sekolah, dan Olahraga (Kepdirjen Diklusepora) Nomor: KEP-105/E/L/1990 sebagai berikut:

Kursus adalah satuan pendidikan luar sekolah yang menyediakan berbagai jenis pengetahuan, keterampilan, dan sikap mental bagi warga belajar yang memerlukan bekal dalam mengembangkan diri, bekerja mencari nafkah dan melanjutkan pendidikannya ke jenjang yang lebih tinggi.

Menurut Kamus Umum Bahasa Indonesia bahwa kursus didefinisikan adalah pelajaran tentang suatu pengetahuan atau kepandaian yang diberikan dalam waktu singkat.

Menurut Kamus Bahasa Indonesia Kontemporer bahwa kursus adalah pengajaran mengenai kemahiran, kepandaian, keahlian, pengetahuan, dan sebagainya dalam waktu singkat.

Menurut para ahli yang di atas dapat disimpulkan bahwa definisi kursus adalah pelayanan warga belajar yang berupa pengetahuan, keterampilan, sikap mental, keahlian, dan kemahiran yang dapat dimanfaatkan bagi meningkatkan mutu kehidupan dan menjadi bekal mencari nafkah serta dapat dimanfaatkan untuk melanjutkan ke jenjang pendidikan yang lebih tinggi dalam waktu yang singkat. ${ }^{23}$

22 Sungkowo Edy Mulyono, Kemiskinan dan Pemberdayaan Masyarakat, (Yogyakarta: Ombak, 2017) hal.105

${ }^{23}$ Gesta Septi Nugraheni, Sekripsi Implementasi Program Kursus Kewirausabaan Kota Di Pusat Kegiatan Belajar Masyarakat (PKBM) Wijaya Kusuma Dalam Peningkatkan Kesejabteraan Keluarga, (Yogyakarta: Universitas Negeri Yogyakarta, 2012) hal.12 
Jadi Short Course adalah kursus pendek atau kursus singkat, sebuah pelayanan belajar berupa pengetahuan, keterampilan, keahlian untuk meningkatkan mutu kehidupan masyarakat untuk menjadi lebih baik lagi dalam waktu singkat atau pendek.

\section{Tujuan Course}

Kursus sebagai salah satu satuan pendidikan pada jalur pendidikan luar sekolah tugas kelembagaan untuk merealisasikan tujuan pendidikan luar sekolah. peraturan pemerintah No.73 tahun 1991 tentang pendidikan luar sekolah. Pasal 2 ayat 1, yaitu "Melayani warga belajar supaya dapat tumbuh dan berkembang sedini mungkin dan sepanjang hayatnya guna meningkatkan martabat dan mutu kehidupannya" (Sihombing,2001:89)

Sejalan dengan tujuan pendidikan luar sekolah maka tujuan penyelenggaraan kursus adalah (1) memperluas keikutsertaan masyarakat dalam pemerataan kesempatan belajar, (2) meningkatkan mutu masyarakat melalui pendidikan, (3) meningkatkan proses belajar mengajar untuk mencapai dayaguna dan hasil guna yang optimal, (4) mempersiapkan warga belajar untuk mengembangkan diri pribadinya atau untuk memperoleh kesempatan kerja yang lebih besar (Sihombing, 2001:89) ${ }^{24}$

Berdasarkan tujuan penelitian, jenis penelitian ini bersifat deskriptif. Penelitian deskriptif pada umumnya dilakukan dengan tujuan utama, yaitu menggambarkan secara sistematis fakta dan karakteristik objek dan subjek yang diteliti secara tepat. Metode deskriptif adalah pencarian fakta dengan interpretasi yang tepat. Metode penelitian yang berusaha menggambarkan objek subjek yang diteliti sesuai dengan apa adanya. ${ }^{25}$ Sedangkan berdasarkan pengumpulan data penelitian ini menggunakan jenis penelitian kualitatif.

Sehingga jenis penelitian ini termasuk jenis penelitian deskriptif kualitatif. Penelitian deskriptif kualitatif yang bertujuan mengelolah dan memanfaatkan data-data yang diperoleh di lapangan, dan menganalisisnya sehingga memperoleh jawaban mengenai gambaran proses pemberdayaan yatim dan dhuafa melalui program Short Course oleh Rumah Gemilang Indonesia.

\footnotetext{
${ }^{24}$ Ibid hal.11

${ }^{25}$ Iwan Hermawan, Metodologi Penelitian Pendidikan Kuantitatif, Kualitatif dan Mixed Methode, (Kuningan: Hidayatul Quran Kuningan, 2019) cet ke-1 hal.37
} 


\section{HASIL DAN DISKUSI}

\section{Gambaran Umum Rumah Gemilang Indonesia Sawangan, Depok}

Awal mula didirikannya lembaga Rumah Gemilang Indonesia ini adalah karena kegelisahan terhadap masalah sosial yang semakin meningkatnya jumlah pengangguran pada kalangan usia produktif, yang mana angka pengangguran yang semakin meningkat namun masih minim solusinya, dan kebanyakan dari mereka adalah yang tidak terdidik dan tidak terampil. Lalu dengan melihat masalah moral Indonesia, yang dapat dilihat dari banyaknya aksi tawuran pada usia pelajar, banyaknya terbentuknya geng motor yang tidak jelas tujuan terbentuknya, banyaknya kriminalitas, minimnya atensi terhadap agama, dan lain-lain.

Sebagai sebuah lembaga zakat, LAZ Al-Azhar ingin menciptakan sebuah inovatif, bahwa zakat mampu untuk memberdayakan usia produktif, lalu disalurkannya melalui beasiswa, namun bukan beasiswa kuliah mapun beasiswa formal yang ada pada pendidikan sekolah pada umumnya, tetapi beasiswa program diklat, yang mana para siswa/i lulusan dari RGI ini diharapkan bisa bekerja secara professional sesuai keterampilan yang dimilikinya, dan juga menjadi manusia yang berakblaqul karimah.

RGI berdiri di lahan wakaf seluas $2.300 \mathrm{M}$ yang bertempat di Kampung Kebon Kopi, Kelurahan Pengasinan, Kecamatan Sawangan, Kota Depok Jawa Barat. Yang mulai beroperasi pada tanggal 1 Juni 2009. RGI adalah sebuah lembaga yang dikelolah oleh LAZ Al-Azhar. RGI didesain sebagai wadah usia produktif, yaitu usia 17 tahun sampai dengan usia 30 tahun, dan diambil dari kalangan keluarga dhuafah dan yatim, dengan tujuan agar Yatim dan Dhuafa tetap bisa belajar layaknya - pada umumnya.

RGI adalah sebuah lembaga yang berbentuk diklat yaitu lembaga pendidikan dan pelatihan. Di RGI diajarkan berbagai macam keterampilan yang sering diminati oleh kalangan. Dan dalam proses diklat lembaga tidak melihat latar belakang mereka, walaupun mereka yang hanya lulusan SD maupun SMP. karena yang hanya lulusan SD dan SMP pun tetap bisa menjadi siswa diklat di RGI.

RGI juga mengadopsi model pesantren yang fokus pendidikan non formal yang dikemas dalam bentuk short course (kursus singkat). Perpaduan ini bertujuan agar para yang menjadi santri RGI tidak hanya menyerap 
pengetahuan yang menjadi pondasi dai masa depan, namun juga memiliki pengetahuan akidah Islam yang baik dan benar. ${ }^{26}$

Tokoh pertama mulanya RGI dibangun adalah pada masa Direktur Bapak Anwar Sani beliau adalah inisiator awal dibangunnya RGI, beliau mempunyai inisiatif membangun sebuah tempat diklat untuk usia produktif, yang mana pada mulanya RGI hanya sebuah lembaga diklat saja, belum adanya fasilitas asrama, dan diklat hanya dilakukan satu pekan atau beberapa hari saja, hingga pada akhirnya RGI dikembangkan seperti sekarang oleh penerus-penerus beliau.

Dan pada masa perintisan Bapak Anwar Sani tersebut, RGI baru membuka 2 kelas keterampilan, yaitu kelas computer dan kelas garmen. Namun sekarang RGI Sawangan Depok telah membuka 8 kelas keterampilan, yaitu kelas tata busana, kelas fotografi dan vidiografi, kelas desain grafis, kelas teknik computer dan jaringan, kelas perkantoran, kelas otomotif, kelas kelistrikan, dan kelas rekayasa perangkat lunak.

Dan RGI juga telah membuka beberapa cabang di beberap daerah, yaitu RGI pusat berada di Sawangan Depok, lalu RGI cabang pertama berada di Jakarta Timur, yang kedua berada di Magelang, yang ketiga berada di Surabaya, yang keempat berada di Aceh, yang kelima berada di Yogyakarta. ${ }^{27}$

Dalam setiap cabang juga memiliki jurusan kelas keterampilan yang berbeda-beda, di Sentra Primer Jakarta Timur membuka kelas keterampilan aplikasi perkantoran. Cabang di Magelang Jawa Tengah membuka kelas desain grafis. Cabang di Surabaya Jawa Timur membuka kelas Tata Busana (khusus perempuan) dan rekayas perangkat lunak (khusus laki-laki). Cabang di Aceh membuka kelas tata busana, otomotif tehnik sepeda motor dan kelistrikan. Dan cabang di Yogyakarta membuka kelas chef halal.

\section{Visi dan Misi}

Visi dan Misi Rumah Gemilang Indonesia

\section{Visi}

26 Rayan Luminaris, Manager Rumah Gemilang Indonesia, wawancara, Gresik Via online, 5 Juni 2020

27 Rayan Asa Luminaries, manager RGI Sawangan-Depok, wawancara, Gresik Via Telepon, 21 April 2020

39 | Bina Ummat | Vol 4 | No. 1 | 2021 
Menjadi pusat pendidikan dan pelatihan keterampilan serta pengembangan masyarakat yang mampu menciptakan generasi kreatif, produktif, mandiri, dan berakhlaq mulia.

\section{Misi}

1. memberikan edukasi kepada masyarakat bahwa pentingnya pendidikan generasi muda, yaitu dengan melakukan promosi dan rekrutmen satri dengan kaidah-kaidah yang telah ditentukan dalam penyeleksian.

2. Berkomitmen penuh dalam menyediahkan fasilitas diklat terbaik sesuai dengan masing-masing kelas.

3. Menjalin kemitraan dengan korporasi, dalam hal penyandang dana operasional.

4. Menjalin kemitraan dengan pemerintah, izin operasional sebagai lembaga diklat non formal dari dinas pendidikan dan dinas perizinan.

5. Memberikan edukasi kepada masyarakat sekitar RGI tentang bagaimana fungsi dari dana zakat ketika dikelolah untuk hal-hal yang produktif.

6. Memberikan edukasi kepada para santri terutama dalam bidang agama, keterampilan dan akhlaq, untuk membangun karakter islam yang terampil, berakhlaq karimah, dan mempunyai komitmen menjadi yang manfaat bagi dirinya, sekitarnya dan juga bangsa negaranya. ${ }^{28}$

Program Pemberdayaan Yatim dan Dhuafa melalui program "Short Course" (Kursus Singkat) Rumah Gemilang Indonesia Sawangan Depok

Adapun program Rumah Gemilang Indonesia Sawangan-Depok dalam melakukan kegiatan pemberdayaan terhadap Yatim dan Dhuafa adalah sebagai berikut:

\section{Program Reguler}

Program regular adalah program keterampilan yang diadakan oleh RGI untuk usia produktif (usia 17-30 tahun). program regular ini dilaksanakan selama 6 bulan lamanya, dalam 6 bulan tersebut terdiri dari:

${ }^{28}$ Rayan Asa Luminaries, manager RGI Sawangan-Depok, wawancara, Gresik Via Telepon, 21 April 2020 


\section{Teori dan praktik (selama 4 bulan)}

Dalam 4 bulan ini para santri mempelajari tentang teori-teori keterampilan sesuai dengan jurusan yang dipilihnya, dan juga kegiatan praktek dari teori yang sudah dipelajarinya. Dalam 4 bulan ini juga terdapat ujian-ujian untuk mengukur sejauh mana kemampuan para santri.

Para santri mengikuti diklat setiap hari senin sampai jum'at fullday, yaitu dari jam 07.00 sampai 17.00

\begin{tabular}{|l|l|}
\hline $00-09.00$ & $\begin{array}{l}\text { npingan spiritual care community, sholat dhuha, dan } \\
\text { aca surat al-waqi'ah }\end{array}$ \\
\hline $00-12.00$ & $\begin{array}{l}\text { keterampilan masing-masing jurusan, teori \& } \\
k\end{array}$ \\
\hline $00-12.30$ & $\begin{array}{l}\text { dzuhur berjama'ah dan kultum yang dibawakan } \\
\text { ntri yang bergantian setiap harinya }\end{array}$ \\
\hline $30-13.30$ & siang, tidur siang \\
\hline $30-15.30$ & $\begin{array}{l}\text { keterampilan masing-masing jurusan, teori \& } \\
\text { k }\end{array}$ \\
\hline $30-16.00$ & $\begin{array}{l}\text { ashar berjama'ah, kultum yang dibawakan oleh } \\
\text { ang bergantian setiap harinya }\end{array}$ \\
\hline $00-17.00$ & $\begin{array}{l}\text { keterampilan masing-masing jurusan, teori \& } \\
\text { k }\end{array}$ \\
\hline
\end{tabular}

\section{Workshop terpadu (selama 1 bulan)}

Setelah mendapatkan teori dan praktik para santri akan melakukan kegiatan workshop terpadu, dalam workshop terpadu ini para santri akan ditugaskan untuk membuat sebuah karya sesuai dengan jurusannya secara berkelompok, dan setelah itu setiap kelompok harus mempresentasikan hasil karyanya, dan workshop terpadu ini dilaksanakan selama 1 bulan lamanya. Menurut bapak Rudiansah selaku Mobile Training \& E Development RGI Sawangan Depok, bahwa workshop terpadu ini semacam sekripsi jika di perguuan tinggi.

a. Magang (selama 1 bulan)

Setelah mendapatkan pengetahuan dan juga melakukan worksop terpadu maka yang terakhir dari rangkaian diklat RGI Sawangan Depok ini adalah magang, yang mana para santri akan dikirim ke tempat-tempat 
perusahaan atau tempat kerja sesuai dengan jurusannya, tujuan dari magang adalah agar para santri dapat lebih jauh mengukur kemampuan dan pengetahuannya setelah mengikuti diklat selama 5 bulan lamanya, dan agar para santri lebih berani terjun lansung ke dunia kerja.

Tempat magang akan dipilihkan oleh manajer RGI, namun jika para santri ada rekomendasi tempat magang maka santri tersebut harus menyerahkan sebuah proposal permohonan dan pihak RGI akan mensurvey tempat tersebut untuk melihat cocok tidaknya dijadikan sebuah tempat magang.

\section{Materi Diklat}

a. Teori dan praktek

b. Spiritual Care Community

Spiritual Care Community atau disingkat menjadi SCC adalah sebuah upaya kegiatan untuk merubah karakter santri RGI Sawangan Depok menjadi karakter yang karimah.

Tujuan SCC adalah merubah hati, pikiran, perkataan dan perbuatan santri menjadi baik, yang mana mengadopsi dari dasa dharma pramuka yang ke 10 yaitu suci dalam pikiran perkataan perbuatan, Yang ditekankan tidak hanya materi yang telah tersampaikan namun juga action perubahan para santri.

Maka dari itu dengan adanya SCC ini diharapkan para santri RGI tidak hanya ahli dalam bidang skill saja namun juga mempunyai karakter yang baik. "disini belajar otomotif, tata busana dan lainnya, tapi tanpa disadari belajar juga tahsin, fiqih, al-Qur'an. Itulah kelebihan dari kami. Karena banyak lembaga pelatihan kerja yang ketika selesai pelatihan akan dimasukkan ke pabrik-pabrik untuk menjadi karyawan atau dikirim menjadi TKI TKW namun ternyata sikap dan perilaku mereka semakin hancur ada yang broken home, selingkuh dn lain sebaginya. Itlah karena tidak ada pendekatan karakter sehingga mereka pintar tetapi semakin muncul permasalahan yang semakin besar"

Di RGI juga tidak hanya melihat perkembangan skillnya yang baik saja namun juga melihat karakter dari setiap santri, dan santri bisa saja dikeluarkan jika tidak ada perubahan baik pada karakternya.

Pembina SCC juga berkontribusi dengan semua pihak dalam pengontrolan para santrinya, terutama dengan Pembina asrama. Jika di dalam asrama ada perilaku santri yang tidak sesuai maka pendamping asrama melaporkan kepada Pembina SCC lalu Pembina SCC mencoba 
untuk menasehatinya baik di dalam kelas ketika materi SCC maupun dipanggil lansung menghadap Pembina SCC di ruang konsultan

Dalam program SCC setiap pekannya ada temanya, seperti tema tentang jujur, dan di akhir pekan Pembina SCC menanyakan selama sepekan sudah melanggar berapa kali. Dan materi dalam kelas yang pertama disampaikan adalah penguatan aqidah lalu selanjutnya tadabbur Al-Qur'an.

Dari program SCC ini pula selain menjadi santri berakblakul karimah diharapakan para santri juga mempunyai bekal Al-Qur'an seminimminimnya sudah menghafal Juz Ammah, jadi ketika para santri sudah lulus dari RGI mereka mampu jika menjadi imam di musholah-musholah lingkungan tempat ia tinggal, dan mampu berceramah di depan umum jika ditunjuk menjadi khotib jum'at di lingkungan ia tinggal. ${ }^{29}$

\section{Factory Tour}

Factory Tour adalah materi tambahan yang diberikan setelah 50-70\% mendapatkan teori dan praktek, para santri akan di ajak kunjungan ke dunia industri, menurut bapak Rudiansah selaku Mobile Training \& E Development bahwa factory tour ini seperti kunjungan industri jika di tingkat sekolah, misalnya kelas foto video pernah ke Metro TV. Dan kegiatan ini setiap kelas jurusan mendapat kesempatan 2 kali berangkat factory tour.

\section{Menulis kreatif dan pengenalan internet}

Menulis kreatif dan pengenalan internet ini adalah sebuah pelatihan untuk menulis tentang produk yang dibuatnya, dan setelah itu dilatih untuk memasarkan di internet, atau menjual produk hasil karyanya dengan bantuan internet. ${ }^{30}$

Workshop terpadu

\section{Pemagangan}

\section{Program pelatihan / jurusan keterampilan)}

a. Kelas tata busana

${ }^{29}$ Kamaludin, Kesantrian atau Pembina Spiritual Care Community, wawancara, Rumah Gemilang Indonesia Sawangan Depok, 7 September 2020

30 Agus Bangun, Manager Rumah Gemilang Indonesia Sawangan Depok 2020, wawancara, Rumah Gemilang Sawangan Depok, 7 September 2020. 
Pada jurusan tata busana ini para santri belajar keterampilan mengenai fashion yaitu merancang sebuah pola pakaian dan mengoperasikan mesin jahit

b. Kelas fotografi dan vidiografi

Pada jurusan fotografi dan vidiografi ini para santri belajar keterampilan mengenai foto dan video, dan bagaimana ia mengoperasikan kamera dengan benar dan professional.

c. Kelas desain grafis

Pada jurusan desain grafis ini para santri akan diajarkan bagaimana menjadi seorang desainer handal

d. Kelas teknik komputer dan jaringan

Pada jurusan teknik komputer dan jaringan, para santri belajar keterampilan mengenai dunia IT, yaitu tentang software, hardware, web, mikrotik, dll.

e. Kelas aplikasi perkantoran

Pada jurusan ini para santri akan belajar keterampilan mengenai dunia perkantoran, terlebih mengenai aplikasi yang ada di perkantoran, seperti Microsoft office dan sosial media

f. Kelas otomotif

Pada jurusan otomotif para santri akan belajar keterampilan mengenai dunia perbengkelan dan mekanik, seperti belajar mengenai kerja mesin, kelistrikan, perbengkelan, dll.

\section{Program Non Reguler}

Pada program non regular ini para santri akan dihadirkan pemateripemateri yang terkait dengan jurusan kelas keterampilan yang ada di RGI Sawangan Depok, kegiatan tersebut bisa dinamakan semacam seminar atau materi tambahan dari pemateri luar. Kegiatan ini dilaksanakan pada hari sabtu dan diikuti oleh seluruh santri RGI Sawangan Depok.

\section{Analisis Pemberdayaan Yatim dan Dhuafa melalui program "Short Course" (Kursus Singkat) Rumah Gemilang Indonesia Sawangan Depok}

Berdasarkan hasil penelitian dari data wawancara, observasi dan dokumentasi yang telah penulis lakukan di Rumah Gemilang Indonesia Sawangan Depok, maka dapat diketahui bahwa upaya Pemberdayaan Yatim dan Dhuafa melalui program "Short Course" (Kursus Singkat) Rumah Gemilang Indonesia Sawangan Depok adalah sebagai berikut: 


\section{Menyadarkan akan potensi yang dimiliki}

Potensi adalah sebuah kemampuan yang dimiliki oleh setiap orang yang mempunyai kemungkinan untuk dikembangkan, begitu juga dimiliki oleh Yatim dan Dhuafa. Namun terkadang seseorang tidak menyadari akan potensi yang dimilikinya, maka dari itu harus ada upaya untuk menyadarkan akan potensi yang dimilikinya. Upaya Rumah Gemilang Indonesia Sawangan Depok dalam menyadarkan potensi yang dimiliki oleh para Yatim dan Dhuafa dilakukan ketika tes masuk menjadi santri Rumah Gemilang Indonesia.

Calon santri RGI Sawangan Depok sangatlah beragam, ada yang datang sudah merasa akan potensi yang dimilikinya, ada juga calon santri yang tidak menyadari akan potensinya, bahkan ada yang tidak memahami akan tujuannya mengapa harus masuk RGI. Ketika kondisi calon santri yang tidak menyadari akan potensi yang dimilikinya maka upaya yang telah dilakukan RGI dalam menyadarkan potensi yang dimiliki calon santri adalah yang pertama dengan melihat hasil tes tulis, di mana dalam tes tulis tersebut para calon santri akan dihadapkan dengan pertanyaan-pertanyaan tentang kejurusan, dan dari hasil tes tulis RGI dapat melihat akan potensi yang dimiliki oleh calon santri.

Kedua yaitu dengan melihat hasil wawancara, dalam tes wawancara calon santri akan ditanya akan potensi gen orangtua, hobi yang dimiliki, dan kebiasaan yang sering dilakukannya. Dari situlah RGI akan mengetahui letak potensi yang dimiliki oleh calon santri, dan diarahkan kepada jurusan yang sesuai dengan potensinya.

Namun menyadarkan akan potensi para, RGI tidak hanya pada sebatas tes masuk menjadi calon santri saja, tetapi juga ketika pada proses KBM, yaitu melihat perkembangan para santri, jika pada proses KBM santri tidak ada perkembangan skill sesuai dengan jurusan yang telah dipilih, maka santri akan diarahkan sesuai dengan potensi yang dimilikinya.

\section{Menfasilitasi untuk pengembangan potensi}

Fasilitas adalah sarana dan pra sarana yang sangat berguna atau bermanfaat untuk mempermudah dalam melakukan suatu kegiatan, dalam hal ini kegiatan belajar mengajar. Fasilitas sangatlah dibutuhkan agar proses belajar mengajar dapat berjalan dengan lancar. Dengan adanya fasilitas dalam kegiatan belajar mengajar diharapkan dapat menjadi penunjang dalam pengembangan potensi peserta didik.

Fasilitas yang lengkap juga dapat meningkatkan minat dan motivasi serta meningkatkan mutu hasil belajar peserta didik, karena dengan adanya

45 | Bina Ummat | Vol 4 | No. 1| 2021 
fasilitas belajar peserta didik akan lebih mudah dalam memahami materi yang disampaikan oleh guru.

Menurut hasil penelitian fasilitas yang disediakan oleh RGI Sawangan Depok dalam usaha mengembangkan potensi para santri sudah sangat lengkap dan baik. "fasilitas yang disediakan RGI Sawangan Depok sudah sangat lengkap" penjelasan Bapak Rudiansah selaku Alumni santri RGI Sawangan Depok dan Mobile Training dan E Developmen. RGI Sawangan Depok telah menyediakan Ruangan berAC, Perpustakaan umum, Musholla, Aula utama, Aula putri, Lapangan olahraga, Asrama dan dapur umum. RGI Sawangan Depok juga telah menyediakan fasilitas sesuai dengan masing-masing kelas jurusan, yaitu sebagai berikut, kelas desain grafis, kelas teori tata busana, kelas praktek tata busana, kelas teknik computer dan jaringan, kelas teori otomotif teknik sepeda motor, kelas praktek otomotif teknik sepeda motor, kelas teori fotografi dan vidiografi, kelas praktek fotografi dan videografi (studio), kelas aplikasi perkantoran. ${ }^{31}$ Dan semua fasilitas yang ada pada setiap kelas jurusan disesuaikan dengan jumlah santri yang ada.

RGI Sawangan Depok telah menyediakan fasilitas yang sangat baik dan lengkap, pihak RGI Sawangan Depok tidak memberikan fasilitas yang setengah-setengah namun dengan totalitas, dengan syarat para santri mau dibina menjadi yang berkeahlian dan berakblakul karimah, karena jika para santri tidak mau dibina dengan baik maka pihak RGI Sawangan Depok siap untuk mengeluarkan santri tersebut. Seperti yang telah dijelaskan oleh Bapak Kamaludin pada wawancara di RGI Sawangan Depok 7 september 2020 "meskipun para santri disini kebanyakan dari latar belakang korban broken home, anak pank, suka tawuran, dan anak yang tidak diperhatikan oleh orang tuanya, namun kita memberikan fasilitas tidak setengahsetengah, semua ruangan di sini berAC, asal mereka mau dibina"

\section{Menanamkan nilai-nilai}

Penanaman nilai adalah sebuah usaha dalam menanamkan suatu karakter yang ingin ditanamkan pada peserta didik dengan tujuan agar peserta didik memiliki karakter yang baik dan benar. Penanaman nilai banyak di lakukan di tempat-tempat belajar, baik pada usia anak-anak, remaja, maupun . Begitu juga RGI sawangan Depok telah melakukan

31 Rudiansah, Alumni Santri Rumah Gemilang Indonesia Sawangan Depok dan Mobile Training \& E Developmen, wawancara via online, 13 September 2020. 
penananaman nilai-nalai pada peserta didiknya sebagai usaha dalam memperbaiki moral negeri.

Penanaman nilai yang telah dilakukan RGI Sawangan Depok diantaranya adalah nilai Sosial kemasyarakat, menanaman nilai sosial kemasyarakatan dikemas dalam sebuah kegiatan-kegiatan sosial, diantaranya: bersih-bersih masjid, bersih-bersih lingkungan di sekitaran lingkungan RGI Sawangan Depok, kerja bakti pemotongan hewan qurban

Penanaman nilai yang selanjutnya adalah nilai Agama, diantaranya yang pertama pembiasaan shalat tepat waktu. Kedua menambah hafalan. Ketiga adab. Keempat menambah wawasan ilmu agama pada santri, seperti pemahaman tentang puasa, mengurus jenazah, sholat, dan lain-lain. Dan penanaman nilai agama dalam hal ini banyak dikemas dalam kegiatan SCC.

Dan dengan adanya penanaman nilai agama tersebut menjadikan santri berubah kea rah yang lebih baik lagi seperti yang telah diungkapkan Bapak Rudiansah ketika penulis mewawancarai beliau "yang tadinya shalatnya masih telat-telat, di RGI jadi tepat waktu, ketika masuk RGI yang awalnya santri hanya hafal beberapa surat dari juz 30 setelah masuk RGI dapat menghatamkan hafalan juz 30 dan juz lainnya, ketika masuk menjadi santri RGI adab santri menjadi baik salah satunya lebih sopan, dan santri dengan kesadaran dirinya sendiri menjadi lebih rajin melakukan puasa sunnah."

\section{Meningkatkan partisipasi}

Partisipasi masyarakat dalam suatu pembangunan adalah keikutsertaan masyarakat atau ambil bagian dari kegiatan pembangunan tersebut guna mencapai tujuan pembangunan yang hendak dicapai. Partisipasi menjadi hal yang sangat penting dalam suatu kegiatan pemberdayaan karena keikutsertaan masyarakat adalah kunci dari keberhasilan sebuah pemberdayaan atau pembangunan.

Partisipasi merupakan wujud dari kesadaran masyarakan akan pentingnya pembangunan yang bertujuan untuk memperbaiki mutu hidup mereka. yang artinya memalui partisipasi yang dilakukan oleh masyarakat berarti, berarti masyarakat benar-benar menyadari bahwa pembangunan tidak hanya dilakukan oleh aparat atau pelaksana kegiatan saja namun juga menuntut keikutsertaan masyarakat.

Dalam ilmu pengembangan masyarakat terdapat empat macam kegiatan partisipasi. Dan menurut hasil penelitian Rumah Gemilang Indonesia Sawangan Depok telah melakukan semua empat macam kegiatan partisipasi tersebut, empat macam kegiatan partisipasi tersebut adalah; 


\section{Partisipasi dalam pengambilan keputusan}

Pada umumnya kegiatan pengambilan keputusan selalu ditetapkan oleh aparat pemegang pembangunan saja tanpa melibatkan masyarakat untuk ikut serta dalam pengambilan keputusan tentang program-program pembangunan yang akan dijalankannya. Namun di Rumah Gemilang Indonesia Sawangan Depok ini pengambilan keputusan melibatkan partisipasi para santrinya terlebih keputusan dalam merancang model pembelajaran, "kita di sini tidak pernah keputusan dari saya sendiri kita selalu mengedepankan musyawarah, partisipasi. Seperti halnya memutuskan model pembelajar. Dalam pengambilan keputusan ini semua orang dapat terlibat di dalamnya supaya tujuan kita tercapai, maka dari itu kita beri kesempatan semua pihak bukan hanya santri" ungkap Bapak Agus Bangun selaku Manager baru RGI Sawangan Depok.

\section{Partisipasi dalam pelaksanaan kegiatan}

Dalam kegiatan partisipasi pelaksaan kegiatan terkadang tidak semua masyarakat mau ikut serta dalam kegiatan namun di dalam Rumah Gemilang Indonesia Sawangan Depok ini semua para santrinya dituntut untuk ikut serta dalam kegiatan, karena itu adalah konsekuensi ketika masuk menjadi santri. Hingga mereka dengan sukarela menjalankan setiap program-program kegiatan. ${ }^{32}$

\section{Partisipasi dalam pemantauan dan evaluasi pembangunan}

Partisipasi dalam hal ini sangat diperlukan, untuk mengetahui perkembangan kegiatan yang sudah dijalankan baik itu masalah-masalah atau kendala-kendala yang ada di dalamnya.

Rumah Gemilang Indonesia telah melakukan partisiapasi dalam hal ini, baik dari pihak pengelolah maupun dari pihak santri. Dari pihak pengelolah jika melihat sesuatu yang tidak sesuai dengan prosedur maka akan dilaporkan dan dimusyawarahkan. Begitu juga dengan santri, melaporkan kepada pengelolah jika ada perilaku temannya yang tidak sesuai untuk dinasehati dan dicari jalan keluar untuk menyelesaikannya.

32 Agus Bangun, Manager baru RGI Sawangan Depok, wawancara, Rumah Gemilang Indonesia Sawangan Depok, 07 September 2020. 


\section{Partisipasi dalam pemanfaatan hasil pembangunan}

Partisipasi dalam pemanfaatan hasil pembangunan ini adalah hal penting yang sering terlupakan dan sering kali menganggap bahwa selesainya kegiatan pembangunan otomatis pemanfaatannya telah sampai pada sasaran, padahal pemerataan hasil pembangunan adalah tujuan utama dari kegiatan pembangunan itu sendiri.

Namun di dalam RGI Sawangan Depok semua terkontrol meskipun telah selesainya kegiatan pembelajaran, dan RGI pun membuat forum Ikatan Alumni Rumah Gemilang Indonesia yang disingkat menjadi IARGI. Dan IARGI ini adalah program dari RGI untuk para alumni santri yang posisinya telah menjadi penerima manfaat dan pemberdayaan ekonominya. Dalam forum tersebut RGI dapat memantau perkembangan mereka setelah 6 bulan dibina, dan melihat apakah mereka dapat memanfaatkan apa yang telah mereka dapatkan atau tidak.

\section{Mengarahkan pada tempat yang tepat}

Tujuan utama dalam kegiatan pembangunan tidak hanya selesainya kegiatan saja, namun memastikan manfaat dari kegiatan tersebut dapat merata dirasakan oleh setiap masyarakat yang mengikutinya. Oleh karena itu mengarahkan masyarakat untuk memanfaatkan dari apa yang didapat atau mengarahkan untuk mengembangkan diri adalah hal yang penting dalam kegiatan pembangunan.

Menurut hasil penelitian di RGI Sawangan Depok ketika selesainya kegiatan diklat maka pihak RGI Sawangan Depok mengarahkan para santrinya untuk mengembangkan dirinya di dunia luar, pihak RGI Sawangan Depok juga memberi pilihan kepada santri lulusannya untuk mengembangkan dirinya di bidang memiliki usaha sendiri, usaha bersama dengan beberapa orang, atau ada juga yang usaha dan memperkejakan orang. RGI Sawangan Depok tidak pernah menjanjikan sebuah pekerjaan untuk para lulusan santrinya, RGI Sawangan Depok hanya mengarahkan santrinya untuk terus mengembangkan dirinya dan menjadi manusia yang bermanfaat di lingkungannya dengan bekal dan modal yang telah diterimanya, dengan begitu menjadikan para alumni santrinya menjadi pribadi yang mandiri.

Seperti yang telah dijelaskan oleh Bapak Rudiansah selaku Alumni santri RGI Sawangan Depok dan Mobile Training dan E Developmen pada wawancara online tanggal 22 Juni 2020. "Dari awal RGI Sawangan Depok 
telah menyampaikan kepada para calon santri bahwa RGI tidak menjanjikan pekerjaan, namun RGI adalah sebuah tempat pendidikan dan pelatihan yang mana ilmu-ilmu yang disampaikan bisa menjadi bekal dan modal bekerja atau berwirausaha. Dilatih selama lima bulan setelah itu kami magangkan, dan itu juga untung-untungan ada yang tempat magang yang lansung memperkerjakan para santri ada juga yang tidak, tergantung perusahan tersebut."

\section{KESIMPULAN}

Berdasarkan hasil penelitian yang peneliti lakukan bahwa Rumah Gemilang Indonesia Sawangan Depok telah banyak melakukan aktifitasnya dalam hal pemberdayaan terhadap Yatim dan Dhuafa melalui program short course dan telah mendapatlkan dampak yang sangat positif bagi para peserta didikinya. Uapaya-upaya pemberdayaan yang dilakukan oleh Rumah Gemilang Indonesia Sawangan Depok antara lain.

Pertama, Menyadarkan akan potensi yang dimiliki, yaitu RGI Sawangan Depok menyadarkan potensi yang dimiliki oleh calon santri karena setiap manusia mempunyai keahlian di bidangnyanya masing-masing, dan upaya RGI Sawangan Depok menyadarkan potensi yang dimiliki oleh para calon santrinya yaitu dengan melihat hasil tes tulis dan tes wawancara ketika masuk hendak menjadi santri RGI Sawangan Depok. Dan tidak hanya itu RGI sawangan Depok juga selalu memantau dan memotivasi akan potensi para santrinya ketika dalam proses KBM.

Kedua, Menfasilitasi untuk pengembangan potensi, yaitu dalam proses pemberdayaan fasilitas adalah hal yang sangat penting, karena dengan adanya fasilitas dapat mempermudah meraih hasil dari tujuan pemberdayaan tersebut. Dan RGI Sawangan Depok telah menyediakan fasilitas yang totalitas dalam pelaksanaan kegiatan pemberdayaan .

Ketiga, Penanaman nilai, yaitu sebuah usaha dalam menanamkan suatu karakter yang ingin ditanamkan pada sesorang dengan tujuan agar memiliki karakter yang baik dan benar, seperti halnya yang telah dilakukan oleh RGI sawangan Depok melakukan penanaman nila-nilai agar para santri menjadi yang peduli lingkungan dan berkarakter Islami. Penanaman nilainilai dikemas dalam kegiatan bersih-bersih masjid, bersih-bersih lingkungan, sholat tepat waktu, menambah hafalan dan lain sebagainya.

Keempat, Partisipaasi, partisipasi dalam pembangunan adalah keikut sertaan masyarakat dalam kegiatan pembangunan, partisipasi dalam 
pembangunan sangat penting karena guna mencapai tujuan kegiatan pembangunan itu sendiri. Terdapat empat macam kegiatan partisipasi, yaitu partisipasi dalam pengambilan keputusan, partisipasi dalam kegiatan, partisipasi dalam pemantauan dan evaluasi pembangunan, partisipasi dalam pemanfaatan hasil pembangunan.

Kelima, Mengarahkan pada tempat yang tepat yaitu mengarahkan masyarakat untuk memanfaatkan dari apa yang didapat dari kegiatan pembangunan atau mengarahkan untuk mengembangkan diri, dan hal tersebut adalah hal yang penting dalam kegiatan pembangunan. RGI Sawangan Depok tidak pernah menjanjikan sebuah pekerjaan bagi para santrinya karena RGI Sawangan Depok bukanlah tempat pelatihan kerja, namun ketika selesainya kegiatan diklat maka pihak RGI Sawangan Depok mengarahkan para santrinya untuk mengembangkan dirinya di dunia luar, pihak RGI Sawangan Depok juga memberi pilihan kepada santri lulusannya untuk mengembangkan dirinya di bidang memiliki usaha sendiri, usaha bersama dengan beberapa orang, atau ada juga yang usaha dan memperkejakan orang.

\section{DAFTAR PUSTAKA}

Anwar, Desy, Kamus Lengkap 100 Miliard, Surabaya: Amelia

Ajat Rukajat, Pendekatan Penelitian Kualitatif, Cet ke-1, Yogyakarta: Deepublish, 2018

Fitrah, Muh., Luthfiyah, Metodologi Penelitian; Penelitian Kualitatif, Tindakan Kelas \& Studi Kasus, cet ke-1

Hermawan, Iwan, Metodologi Penelitian Pendidikan Kuantitatif, Kualitatif dan Mixed Methode, Cet ke-1, (Kuningan: Hidayatul Quran Kuningan, 2019)

Huraerah, Abu, Pengorganisasian dan Pengembangan Masyarakat, Cet.1 Humaniora: Bandung, 2008

Kasyaf, Ben Akrom S., Dasyatnya Menyantuni Anak Yatim, Cet.1, Jakarta Timur: Al Maghfiroh, 2012

Mulyono, Sungkowo Edy, Kemiskinan dan Pemberdayaan Masyarakat, Yogyakarta: Ombak, 2017

Mulyana, Deddy, Metodologi Penelitian Kualitatif, Cet. V Bandung: PT Remaja Rosdakarya, 2006 
Nugraheni, Gesta Septi, Sekripsi Implementasi Program Kursus Kewirausahaan Kota Di Pusat Kegiatan Belajar Masyarakat (PKBM) Wijaya Kusuma Dalam Peningkatkan Kesejahteraan Keluarga, Yogyakarta: Universitas Negeri Yogyakarta, 2012

Saleh, Muwafik, Manajemen Training: Teknik Praktis Pengelolaan Training dan Pelatihan Sumber Daya Cet. Pertama, Malang: UB Press, 2016

Sari, Nurdiana Ratna, Sekripsi Pengembangan Anak Dhu'afa Melalui Pendidikan Non Formal Di Yayasan Mizan Amanah, Jakarta: Universitas Islam Negeri Jakarta, 2011

Sugiyono, Metode Penelitian Pendidikan Pendekatan Kuantitatif, Kualitatif, dan R\&D), Cet ke-21, Bandung: ALFABETA, 2015

Sya'bi, Achmad, Kamus An-Nur, Surabaya: Halim Jaya, 1997

Theresia, Aprillia, Krisnha, Dkk. Pembangunan Berbasis Masyarakat, cet.2, Bandung: Alfabeta, 2015)

Yunus, Rabina dan Mansyur Radjab, Ananlisis Pengentasan Kemiskinan, cetakan pertama, Makasar: CV.Sosial Politic Genius, 2018

Yusuf, Muri, Metode penelitian Kuantitatif, Kualitatif \& Penelitian Gabungan, cet ke-4 Jakarta: KENCANA, 2017

Dwi Kartina Ningsih, Satu Langkah Untuk Indonesia Gemilang, diakses dari http://Rumahgemilang.com/satu-langkah-untuk-Indonesia-gemilang/ pada tanggal.5 Juli 2019 pukul.23.00

Nahdiyah, Bab I pendabuluan A.Latar Belakang Penelitian, diakses dari https://www.google.com/url? sa=t\&source=web\&rct=j\&url=http://d igilib.uinsgd.ac.id/11570/4/4 bab1.pdf\&ved=2ahUKEwj17I_juebrAh XkILcAHVuNBJwQFjAAegQIAhAB\&usg=AOvVaw0VEj4mrNOeN kMy08CRxqQ6, pada tanggal 5 juli 2019, pukul 02.00

Dwi Kartika Ningsi, Satu Langkah Untuk Indonesia Gemilang, diakses dari http://umahgemilang.com/satu-langkah-untuk-Indonesia-gemilang/, pada tanggal 3 juli 2019, pukul 11.20

Rumah Gemilang Indonesia, Trendsetter Pemberdayaan Produktif, diakses dari http://rumahgemilang.com, pada tanggal 5 juli 2019, pukul 03.30 
Ridhuan Habibie, "Kisah Mantan OB Yang Sukses Keliling Dunia Berkat RGI", diakses dari https://www.google.com/amp/s/m.liputan6.com/amp/2852038/kisa h-mantan-ob-yang-sukses-keliling-dunia-berkat-rgi, pada tanggal 8 Juli 2019, pukul 06.45

Arie Liliyah, "Mrino : Tukang Las ini Sukses Jadi Pengusaha Neon Box", diakses dari https://swa.co.id/kumparan/marino-tukang-las-yangsukses-jadi-pengusaha-neon-box, pada tanggal 14 September 2019, pukul 19.30

Rumah Gemilang, Sejarah Singkat, diakses dari http://rumahgemilang.com/profil/sejarah-singkat/, pada tanggal 3 juli 2019, pukul 11.30

Ruang Guru, - Pengertian, Jenis, Masalah, Realitas, Dasar Pembinaan dan Peranannya Lengkap, diakses dari https://www.ruangguru.co.id/pengertian--lengkap/ pada tanggal 02 Januari 2019 pukul. 07.40

\section{Wawancara}

Rayan Asa Luminaries, manager RGI Sawangan-Depok, wawancara, Gresik Via Telepon, 21 April 2020

Kamaludin, Kesantrian atau Pembina Spiritual Care Community, wawancara, Rumah Gemilang Indonesia Sawangan Depok, 7 September 2020

Agus Bangun, Manager baru RGI Sawangan Depok, wawancara, Rumah Gemilang Indonesia Sawangan Depok, 07 September 2020

Rudiansah, Alumni Santri Rumah Gemilang Indonesia Sawangan Depok dan Mobile Training \& E Developmen, wawancara via online, 13 September 2020. 